\title{
Effect of Integrated Potassium Management on Soil Biological Properties and Yields of Corn under Corn-Wheat Cropping System
}

\author{
Sanjeev Kumar ${ }^{1 *}$, Shiva Dhar ${ }^{2}$, Sharmistha Barthakur ${ }^{3}$, M. Chandrakala ${ }^{4}$, \\ S.A. Kochewad ${ }^{5}$, L.R. Meena ${ }^{6}$, L.K. Meena ${ }^{6}$, Sudhir Kumar ${ }^{7}$, \\ Magan Singh $^{1}$ and Dileep Kumar ${ }^{8}$
}

ICAR-National Dairy Research Institute, Karnal Haryana 132001, India

${ }^{2}$ Division of Agronomy, ICAR-Indian Agricultural Research Institute, New Delhi 110 012, India

${ }^{3}$ ICAR-National Research Centre for Plant Biotechnology, New Delhi 110 012, India

${ }^{4}$ ICAR - National Bureau on Soil Survey and Land Use Planning, Bengaluru - 560024, India

${ }^{5}$ ICAR-Indian Veterinary Research Institute, Bareilly U.P. 243122, India

${ }^{6}$ ICAR-Indian Institute of Farming Systems Research, Modipuram, Meerut 250 110, India

${ }^{7}$ ICAR-Indian Agricultural Research Institute, New Delhi 110 012, India

${ }^{8}$ ICAR-Indian Institute of Sugarcane Research, Lucknow 226002, India

*Corresponding author

\section{A B S T R A C T}

Keywords

Integrated potassium management, Soil biological properties, Corn, Corn-wheat cropping system

\section{Article Info}

Accepted:

15 November 2018

Available Online:

10 December 2018
Potassium fertilization is often ignored in cereal-based cropping systems assuming sufficient $\mathrm{K}$ reserves in the alluvial soils of north-western India. However, the responses to $\mathrm{K}$ have now widely reported due to continuous mining and little additions through external sources. Little known on the effects of integrated $\mathrm{K}$ management on soil biological properties and yield performance of corn grown in sequence with wheat. A field experiment was conducted during 2010-2012 to find out the performance of corn (Zea mays L.)-wheat (Triticum aestvum L. emend Fiori \& Paol.) cropping system with $\mathrm{K}$ fertilization through muriate of potash and farmyard manure (FYM) at New Delhi, India. The experiment was laid out in the randomized block design with seven treatments replicated thrice. Results revealed that treatment applied with $90 \mathrm{~kg} \mathrm{~K}$ supplemented $60 \mathrm{~kg}$ $\mathrm{K}$ through MOP and $30 \mathrm{Kg} \mathrm{K}$ through FYM significantly increase grain yield (100.9\% and 99.3\%) and stover yield (45.8\% and 33.6\%) during 2010 and 2011 respectively in the corn crop. A positive correlation observed between yield and soil biological properties, viz., bacterial population, actinomycetes, cellulose degrading bacteria, phosphorus solubilizing bacteria, potassium solubilizing bacteria, dehydrogenase activity, phosphatase activity, fluorescein diacetate and $\beta$-glucosidase. It concluded that application of FYM could be an alternative option for sustainable management of agricultural land and restore its fertility compared to the use of $\mathrm{K}$ fertilizers. 


\section{Introduction}

Corn is among the important cereal crops to meet food, feed, fodder and industrial needs of the country. It is often grown in sequence with wheat in the alluvial soils of north-western India. The corn-wheat cropping is very exhaustive regarding nutrient removal from the soil. Again, due to the imbalanced application of vital nutrients like $\mathrm{N}$ and $\mathrm{P}$, the $\mathrm{K}$ is becoming deficient in soils. Removal of $\mathrm{K}$ in proportion to $\mathrm{N}$ is very high in cropping systems, particularly in those involving cereal and fodder crops. It has been observed that even with the recommended levels of fertilizer application, there is enormous negative $\mathrm{K}$ balance under different cropping systems (Yadav et al., 1998).

Potassium $(\mathrm{K})$ is one of the vital nutrients for growth and yield of crops. Most of the crops absorb a significant amount of $\mathrm{K}$ from the rhizospheric soil through roots (Steingrobe and Claassen, 2000). It plays a crucial role in antagonistic and synergistic interaction with other essential nutrients (Dibb and Thompson, 1985). Potassium improves root growth, drought resistance, and enhances translocation and assimilation of nutrients, resulting in the production of starch and protein-rich grain, and reduction of crop lodging and diseases (Dobermann, 2001; Polara et al., 2009; Nejad et al., 2010).

Soil biological activity is a driving force in degradation and conservation of exogenous plant material and anthropogenic depositions, transformations of organic matter, and evolution and maintenance of soil structure (Canarutoo et al., 1995; Bandick and Dick, 1999). The activity of secondary trophic levels depends upon the energy obtained by primary decomposers of organic matter in soils. In turn, this activity plays a primary function in nutrient cycling and support of plant life (Clarholm and Rosengren-Brinck, 1995; Bolata et al., 2003). The population of microbes and enzymatic activity in the soil play a crucial role in maintaining soil fertility and its health through bringing changes by their biochemical processes (Nannipieri et al., 2003; Okore et al., 2012).

The present study was conducted to study the effect of the application of integrated $\mathrm{K}$ fertilization on soil biological activities (enzymatic activity and microbial population) and crop yield under corn-wheat cropping system.

\section{Materials and Methods}

\section{Experimental site}

The field experiment conducted on corn during the rainy season (July-October) and wheat during the winter season (NovemberApril) of 2010-11 and 2011-12 at research farm of Indian Agricultural Research Institute, New Delhi (India) situated in north-western India (28.35 N, 77.12' E) and at $229 \mathrm{~m}$ above mean sea level. The daily minimum and maximum temperatures during the growth period of corn ranged between $19.8^{\circ} \mathrm{C}$ and $38.5^{\circ} \mathrm{C}$, respectively during 2010 , while in 2011 , it ranged between $22.0^{\circ} \mathrm{C}$ and $38.2^{\circ} \mathrm{C}$. The total rainfall received during the corn growing season of 2010 and 2011 was 763 and $465 \mathrm{~mm}$ with 35 and 30 rainy days, respectively. High intensity and uneven distribution of rain observed during rainy season 2010; whereas the intensity was low, and distribution of rainfall was even in rainy season 2011.

The daily minimum and maximum temperatures during the growing period of wheat were $2.0^{\circ} \mathrm{C}$ and $35.4^{\circ} \mathrm{C}$, respectively during 2010-11. In 2011-12, daily minimum and maximum temperatures ranged from 0 to $39.0^{\circ} \mathrm{C}$. Wheat crop received $65.6 \mathrm{~mm}$ rainfall with 11 rainy days during 2010-11and 40.8 mm rainfall with 4 rainy days during 2011-12. 
The experimental soil characterized as sandy loam having $\mathrm{pH} 8.0, \mathrm{EC} 0.43 \mathrm{dSm}^{-1}$ organic carbon $0.4 \%$ available $\mathrm{N} 173.3 \mathrm{~kg} \mathrm{ha}^{-1}$, available $\mathrm{P} 13.8 \mathrm{~kg} \mathrm{ha}^{-1}$ and available K 261 $\mathrm{kg} \mathrm{ha}^{-1}$. The experiment was carried out in the randomized block design with three replications. Seven treatments were applied to corn (M) in the rainy season and wheat (W) in the winter season at the fixed site. Recommended doses of $150 \mathrm{~kg} \mathrm{~N} \mathrm{ha}^{-1}$ and 26 $\mathrm{kg} \mathrm{P} \mathrm{ha}{ }^{-1}$ applied to corn through urea and diammonium phosphate (DAP), respectively. The full dose of $\mathrm{P}$ and $\mathrm{K}$ applied as basal, whereas $50 \mathrm{~kg} \mathrm{~N} \mathrm{ha}^{-1}$ was given as basal and remaining $100 \mathrm{~kg} \mathrm{~N}^{-1}$ was applied in two equal splits at 30 and 60 days after sowing (DAS). Muriate of potash (MOP) and farmyard manure (FYM) used as sources of K. Wheat was given $120 \mathrm{~kg} \mathrm{~N} \mathrm{ha}^{-1}$ through urea and $26 \mathrm{~kg} \mathrm{P}^{-1}$ harough DAP. The FYM applied analyzed for $\mathrm{N}, \mathrm{P}, \mathrm{K}$ content and recorded 5 and $6 \mathrm{~g} \mathrm{~N} \mathrm{~kg}^{-1}, 4$ and $4 \mathrm{~g} \mathrm{P} \mathrm{kg}^{-1}$ and 5 and $4 \mathrm{~g} \mathrm{~K} \mathrm{~kg}^{-1}$ FYM applied in the field during 2010 and 2011, respectively. The amount of $\mathrm{N}, \mathrm{P}$, and $\mathrm{K}$ applied through urea, DAP and FYM were adjusted in all the treatments to maintain the required nutrient combinations. The final amount of N, P and K had given to corn and wheat crop as shown in Table 1. The corn hybrid 'PEHM2' (CM137 X CM138) was sown at $60 \mathrm{~cm} \times 20 \mathrm{~cm}$ spacing, using $20 \mathrm{~kg}$ seed ha ${ }^{-1}$. The wheat variety 'HD 2967 ' resistant to rust with a moderate level of resistance to the $\mathrm{Ug}_{99}$ race of stem rust was selected for this study.

\section{Microbial count and enzymatic activity in soil}

For microbial and enzymatic studies, the soil collected from the rhizosphere of crop plants at maturity. The microbial population counted by preparing appropriate serial dilutions for bacteria, actinomycetes, $\mathrm{P}$ solubilizers, K solubilizers and cellulose degraders. The nutrient agar, Kenknight and Munaier's agar,
Pikovaskiya agar, Aleksandrov medium and carboxymethyl cellulose (CMC) agar media were used for enumeration of bacteria, actinomycetes, $\mathrm{P}$ solubilizers, $\mathrm{K}$ solubilizers and cellulose degraders respectively. The dehydrogenase activity and fluorescein diacetate (FDA) was calculated by following Green et al., (2006) and Klein et al., (1971), respectively. Acid phosphatase and alkaline phosphatase activities were determined colorimetrically by a visible spectrophotometer (Tabatabai and Bremner, (1969). $\beta$-glucosidase activity was estimated colorimetrically by a visible spectrophotometer (Evazi and Tabatabai, 1988).

\section{Chemical soil and plant analysis}

Soil samples were collected from the field and mixed thoroughly, air-dried, sieved and analyzed for available $\mathrm{N}$ by alkaline $\mathrm{KMnO}_{4}$ method (Subbiah and Asija, 1956), 0.5 N Nabicarbonate extractable $\mathrm{P}$ (Olsen et al., 1954), $\begin{array}{lllll}\text { and } & 1.0 & \mathrm{~N} & \mathrm{NH}_{4} \mathrm{OAc}-\text { extractable } \mathrm{K}\end{array}$ (Jackson, 1967).

\section{Measurement of plant growth parameters and yield of corn}

Harvesting of corn and wheat was carried out in an area of $4.8 \mathrm{~m}^{2}$ and $4.5 \mathrm{~m}^{2}$ from the center of each plot manually. Dry weights of stems and grains were measured separately. The grain and stover/straw yield calculated through the weight of dried plant samples and converted in ton per hectare.

\section{Statistical analysis}

The experimental data analyzed by applying the "Analysis of Variance" technique for randomized block design (Gomez and Gomez 1984). The standard error of mean (SEm \pm ), least significant difference (LSD) at $\mathrm{P} \leq 0.05$ probability were worked out. The correlation 
studies performed using SPSS programme (version 16.0).

\section{Results and Discussion}

\section{Yields of corn and wheat}

Grain and stover yield of corn differed significantly due to $\mathrm{K}$ application (Table 2). All the treatments supplied with $\mathrm{K}$ showed significant superiority over no $\mathrm{K}$ treatments for grain yield. The corn gave the highest grain yield of $4.44 \mathrm{t} \mathrm{ha}^{-1}$ (2010), and $5.42 \mathrm{t}$ $\mathrm{ha}^{-1}$ (2011) under treatment applied with $90 \mathrm{~kg}$ $\mathrm{K} \mathrm{ha}^{-1}$ supplemented $60 \mathrm{~kg} \mathrm{~K}$ through MOP and $30 \mathrm{~kg} \mathrm{~K} \mathrm{ha}^{-1}$ through FYM $\left(\mathrm{T}_{3}\right)$. The treatment $\mathrm{T}_{3}$ produced $27.7 \%$ and $19.4 \%$ higher yield over $\mathrm{T}_{2}$ and $\mathrm{T}_{4}$ during 2010, and $10.8 \%$ and $12.4 \%$, during 2011 , respectively.

The treatment $T_{2}$ and $T_{4}$ applied with $30 \mathrm{~kg} \mathrm{~K}$ $\mathrm{ha}^{-1}$ through FYM+30 kg K ha ${ }^{-1}$ through MOP also proved significantly superior over treatment $\mathrm{T}_{5}$ and $\mathrm{T}_{6}$ which involved $60 \mathrm{~kg} \mathrm{~K}$ though MOP alone. Stover yield followed the trend of grain yield during 2010, whereas during 2011, all the treatments applied with $\mathrm{K}$ were found at par with each other and significantly superior to control $\left(\mathrm{T}_{1}\right)$. On the other hand, the highest grain yield of wheat was obtained with treatment applied with 90 $\mathrm{kg} \mathrm{K} \mathrm{ha}{ }^{-1}$ supplemented $60 \mathrm{~kg} \mathrm{~K}$ through MOP and $30 \mathrm{~kg} \mathrm{~K} \mathrm{ha}{ }^{-1}$ through FYM $\left(\mathrm{T}_{7}\right)$ during 2010-11 (5.39 t ha-1) and 2011-12(5.49 $\left.\mathrm{t} \mathrm{ha}^{-1}\right)$. Treatment $\mathrm{T}_{7}$ also gave the highest straw yield of $8.20 \mathrm{t} / \mathrm{ha}$ and $8.98 \mathrm{t} / \mathrm{ha}$, respectively.

\section{Nutrient availability in rhizospheric soil}

A decline in the availability of different nutrients in the soil, irrespective of treatments applied over the initial amount of nutrients (Table 3). All the treatments applied with integrated $\mathrm{K}$ management showed a significant increase in nutrient availability over the remaining treatments compared with treatment applied with $\mathrm{K}$ through MOP alone and treatment applied with no $\mathrm{K}\left(\mathrm{T}_{1}\right)$. During 2010 and 2011, treatment applied with $60 \mathrm{~kg}$ $\mathrm{K} \mathrm{ha}^{-1}$ supplemented $30 \mathrm{~kg} \mathrm{~K}^{-1}$ through MOP and $30 \mathrm{~kg} \mathrm{~K} \mathrm{ha}^{-1}$ through FYM in corn and $60 \mathrm{~kg} \mathrm{~K} \mathrm{ha}^{-1}$ in wheat crop through MOP alone $\left(\mathrm{T}_{2}\right)$ showed highest $\mathrm{N}\left(188.3 \mathrm{~kg} \mathrm{ha}^{-1}\right.$ and $\left.190.0 \mathrm{~kg} \mathrm{ha}^{-1}\right)$ and $\mathrm{P}$ availability $(14.7 \mathrm{~kg}$ $\mathrm{ha}^{-1}$ and $15.4 \mathrm{~kg} \mathrm{ha}^{-1}$ ).

The treatment (T2) followed by treatment applied with $60 \mathrm{~kg} \mathrm{~K} \mathrm{ha}^{-1}$ supplemented $30 \mathrm{~kg}$ $\mathrm{K} \mathrm{ha}^{-1}$ through MOP and $30 \mathrm{~kg} \mathrm{~K} \mathrm{ha}^{-1}$ through FYM in corn and no $\mathrm{K}$ in wheat crop $\left(\mathrm{T}_{4}\right)$ and treatment applied with $90 \mathrm{~kg} \quad \mathrm{~K}^{-1}$ supplemented $60 \mathrm{~kg} \mathrm{~K} \mathrm{ha}^{-1}$ through MOP and $30 \mathrm{~kg} \mathrm{~K} \mathrm{ha}^{-1}$ through FYM in corn and no $\mathrm{K}$ in wheat crop $\left(\mathrm{T}_{3}\right)$. Availability of $\mathrm{K}$ was the highest in treatment $\mathrm{T}_{3}(258.9 \mathrm{~kg} / \mathrm{ha}$ and 239.3 $\mathrm{kg} / \mathrm{ha}$ ), which showed significant superiority over remaining treatments.

\section{Microbial count}

The significant increase observed in the total bacterial count, P solubilizers, actinomycetes, cellulose degraders and $\mathrm{K}$ solubilizing bacteria in treatments applied with integrated $\mathrm{K}$ management (Fig. 1).

Highest bacterial counts, P solubilizers, actinomycetes, cellulose degraders and $\mathrm{K}$ solubilizing bacterial counts recorded in treatment applied with $90 \mathrm{~kg} \quad \mathrm{~K} \quad \mathrm{ha}^{-1}$ supplemented $60 \mathrm{~kg} \mathrm{~K} \mathrm{ha}^{-1}$ through MOP and $30 \mathrm{~kg} \mathrm{~K} \mathrm{ha}^{-1}$ through FYM in corn and no $\mathrm{K}$ in the wheat crop $\left(\mathrm{T}_{3}\right)$.

The treatment $\mathrm{T}_{3}$ followed by treatment applied with $60 \mathrm{~kg} \mathrm{~K}^{-1} \mathrm{ha}^{-1}$ supplemented $30 \mathrm{~kg}$ $\mathrm{K} \mathrm{ha}^{-1}$ through MOP and $30 \mathrm{~kg} \mathrm{~K} \mathrm{ha}^{-1}$ through FYM in corn and $60 \mathrm{~kg} \mathrm{~K} \mathrm{ha}^{-1}$ in wheat crop $\left(\mathrm{T}_{2}\right)$ and treatment applied with $90 \mathrm{~kg} \mathrm{~K} \mathrm{ha}^{-1}$ supplemented $30 \mathrm{~kg} \mathrm{~K}^{-1} \mathrm{ha}^{-1}$ through MOP and $30 \mathrm{~kg} \mathrm{~K} \mathrm{ha}^{-1}$ through FYM in corn and no $\mathrm{K}$ in wheat crop $\left(\mathrm{T}_{4}\right)$. 


\section{Enzymatic activity}

All the treatments applied with integrated $\mathrm{K}$ management showed the significant increase in dehydrogenase activity, FDA activity, $\beta$ glucosidase activity, acid phosphatase and alkaline phosphatase activity (Fig. 2).

The treatment applied with $90 \mathrm{~kg} \mathrm{~K} \mathrm{ha}{ }^{-1}$ supplemented $60 \mathrm{~kg} \mathrm{~K} \mathrm{ha}^{-1}$ through MOP and $30 \mathrm{~kg} \mathrm{~K} \mathrm{ha}^{-1}$ through FYM in corn, and no $\mathrm{K}$ in the wheat crop $\left(\mathrm{T}_{3}\right)$ showed significant superiority over all the treatments for dehydrogenase activity, FDA activity, $\beta$ glucosidase activity, acid phosphatase and alkaline phosphatase activity.
Pearson's correlation matrix between yield, and enzymatic activities and microbial count

Significant and positive correlations were observed $(P=0.01)$ between yield with bacterial count $(\mathrm{r}=0.812), \mathrm{P}$ solubilizers $(\mathrm{r}=0.798)$, actinomycetes $(\mathrm{r}=0.705)$, cellulose degraders $(\mathrm{r}=0.799), \mathrm{K}$ solubilizing bacteria $(\mathrm{r}=0.752)$, dehydrogenase activity $(\mathrm{r}=0.814)$, FDA $(r=0.752), \beta$ - glucosidase $(r=0.803)$, acid phosphatase $(\mathrm{r}=0.825)$, alkaline phosphatase $(\mathrm{r}=0.758)$ as shown in (Table 4$)$.

Table.1 Designing of various treatments for integrated potassium fertilization under corn-wheat cropping system

\begin{tabular}{|l|l|l|l|l|l|}
\hline Symbol & Treatment detail & Crop & \multicolumn{3}{|l|}{ Amount of nutrient } \\
applied (kg/ha)
\end{tabular}


Int.J.Curr.Microbiol.App.Sci (2018) 7(12): 1855-1866

Table.2 Effect of integrated $\mathrm{K}$ fertilization on yield $\left(\mathrm{t} \mathrm{ha}^{-1}\right)$ of corn and wheat

\begin{tabular}{|c|c|c|c|c|c|c|c|c|}
\hline \multirow[t]{3}{*}{ Treatment } & \multicolumn{4}{|c|}{ Corn } & \multicolumn{4}{|c|}{ Wheat } \\
\hline & \multicolumn{2}{|c|}{ Grain } & \multicolumn{2}{|c|}{ Stover } & \multicolumn{2}{|c|}{ Grain } & \multicolumn{2}{|c|}{ Straw } \\
\hline & 2010 & 2011 & 2010 & 2011 & 2010-11 & 2011-12 & 2010-11 & 2011-12 \\
\hline $\mathbf{T}_{1}$ & 2.21 & 2.72 & 4.48 & 5.26 & 3.80 & 3.89 & 7.30 & 7.59 \\
\hline $\mathbf{T}_{2}$ & 3.68 & 4.89 & 5.90 & 6.75 & 4.94 & 5.05 & 8.13 & 8.53 \\
\hline $\mathbf{T}_{\mathbf{3}}$ & 4.44 & 5.42 & 6.53 & 7.03 & 4.22 & 4.31 & 7.78 & 8.09 \\
\hline $\mathbf{T}_{4}$ & 3.72 & 4.82 & 5.83 & 6.62 & 4.10 & 4.19 & 7.76 & 8.07 \\
\hline $\mathbf{T}_{5}$ & 2.99 & 4.30 & 5.14 & 6.53 & 5.05 & 5.16 & 8.14 & 8.77 \\
\hline $\mathbf{T}_{6}$ & 3.02 & 4.21 & 5.21 & 6.43 & 4.81 & 4.88 & 7.93 & 8.24 \\
\hline $\mathbf{T}_{7}$ & 2.21 & 3.20 & 4.47 & 5.83 & 5.39 & 5.49 & 8.20 & 8.98 \\
\hline LSD & 0.57 & 0.61 & 0.50 & 0.78 & 0.45 & 0.47 & NS & NS \\
\hline
\end{tabular}

Note: for treatment details $\left(T_{1}\right.$ to $\left.T_{7}\right)$ see Table 2 .

Table.3 Effect of integrated potassium fertilization on nutrient availability after corn harvest

\begin{tabular}{|c|c|c|c|c|c|c|c|}
\hline \multirow{2}{*}{ Treatment } & \multicolumn{2}{|c|}{ Available N } & \multicolumn{3}{|c|}{ Available P } & \multicolumn{2}{c|}{ Available K } \\
\cline { 2 - 8 } & $\mathbf{2 0 1 0}$ & $\mathbf{2 0 1 1}$ & $\mathbf{2 0 1 0}$ & $\mathbf{2 0 1 1}$ & $\mathbf{2 0 1 0}$ & $\mathbf{2 0 1 1}$ \\
\hline $\mathbf{T}_{\mathbf{1}}$ & 166.3 & 157.4 & 13.6 & 12.9 & 217.5 & 177.9 \\
\hline $\mathbf{T}_{\mathbf{2}}$ & 188.3 & 190.0 & 14.7 & 15.4 & 250.6 & 228.6 \\
\hline $\mathbf{T}_{\mathbf{3}}$ & 179.2 & 176.2 & 14.5 & 14.5 & 258.9 & 239.3 \\
\hline $\mathbf{T}_{\mathbf{4}}$ & 187.8 & 186.2 & 14.7 & 14.7 & 251.0 & 221.8 \\
\hline $\mathbf{T}_{\mathbf{5}}$ & 169.3 & 177.3 & 14.5 & 15.2 & 235.1 & 213.2 \\
\hline $\mathbf{T}_{\mathbf{6}}$ & 169.2 & 158.6 & 14.6 & 14.5 & 233.9 & 207.1 \\
\hline $\mathbf{T}_{\mathbf{7}}$ & 165.4 & 174.4 & 13.6 & 14.0 & 217.5 & 200.0 \\
\hline LSD $(\boldsymbol{P}=\mathbf{0 . 0 5})$ & 7.9 & 5.7 & 0.4 & 0.6 & 8.0 & 9.4 \\
\hline
\end{tabular}


Table.4 Pearson's correlation matrix between yield, microbial count and enzymatic activities in rhizospheric soil after harvest of corn (mean of two years)

\begin{tabular}{|c|c|c|c|c|c|c|c|c|c|c|c|}
\hline Parameter & $\begin{array}{l}\text { Grain } \\
\text { yield }\end{array}$ & $\begin{array}{c}\text { Bacterial } \\
\text { count }\end{array}$ & $\begin{array}{l}\text { Phosphorus } \\
\text { solubilizers }\end{array}$ & $\begin{array}{l}\text { Actino- } \\
\text { mycetes }\end{array}$ & $\begin{array}{l}\text { Cellulose } \\
\text { degraders }\end{array}$ & $\begin{array}{l}\text { K solubilizing } \\
\text { bacteria }\end{array}$ & $\begin{array}{l}\text { Dehydrogen- } \\
\text { ase activity }\end{array}$ & FDA & $\begin{array}{c}\text { Beta } \\
\text { glycosidase }\end{array}$ & $\begin{array}{c}\text { Acid } \\
\text { phosphatase }\end{array}$ & $\begin{array}{l}\text { Alkaline } \\
\text { phosphatase }\end{array}$ \\
\hline Grain Yield & 1 & $0.812^{* * *}$ & $0.798^{* *}$ & $0.705^{* *}$ & $0.799^{* *}$ & $0.752^{\text {** }}$ & $0.814^{* *}$ & $0.752^{* *}$ & $0.803^{* *}$ & $0.825^{* * *}$ & $0.758^{* *}$ \\
\hline Bacterial Count & & 1 & $0.999^{* *}$ & $0.978^{* *}$ & $0.988^{* *}$ & $0.972^{* *}$ & $0.981^{* *}$ & $0.959^{* *}$ & $0.976^{* *}$ & $0.989^{* *}$ & $0.969^{* *}$ \\
\hline $\begin{array}{l}\text { Phosphorus } \\
\text { solubilizers }\end{array}$ & & & 1 & $0.982^{* *}$ & $0.983^{* *}$ & $0.9784^{* *}$ & $0.973^{* *}$ & $0.954^{* *}$ & $0.969^{* *}$ & $0.983^{* *}$ & $0.964^{* *}$ \\
\hline Actinomycetes & & & & 1 & $0.953^{* *}$ & $0.983^{* *}$ & $0.940^{* *}$ & $0.960^{* *}$ & $0.952^{* *}$ & $0.955^{* *}$ & $0.961^{* *}$ \\
\hline $\begin{array}{l}\text { Cellulose } \\
\text { degraders }\end{array}$ & & & & & 1 & $0.941^{* *}$ & $0.994^{* *}$ & $0.935^{* *}$ & $0.968^{* *}$ & $0.990^{* *}$ & $0.950^{*}$ \\
\hline $\begin{array}{l}\text { K solubilizing } \\
\text { bacteria }\end{array}$ & & & & & & 1 & $0.918^{* *}$ & $0.916^{* *}$ & $0.917^{* *}$ & $0.937^{* *}$ & $0.917^{* *}$ \\
\hline $\begin{array}{l}\text { Dehydrogenase } \\
\text { activity }\end{array}$ & & & & & & & 1 & $0.952^{\text {** }}$ & $0.984^{* *}$ & $0.997^{* *}$ & $0.965^{* *}$ \\
\hline FDA & & & & & & & & 1 & $0.990^{* *}$ & $0.967^{* *}$ & $0.997^{* *}$ \\
\hline Beta glycosidase & & & & & & & & & 1 & $0.991^{* *}$ & $0.995^{* *}$ \\
\hline $\begin{array}{l}\text { Acid } \\
\text { phosphatase }\end{array}$ & & & & & & & & & & 1 & $0.976^{* *}$ \\
\hline $\begin{array}{l}\text { Alkaline } \\
\text { phosphatase }\end{array}$ & & & & & & & & & & & 1 \\
\hline
\end{tabular}

* Significant at the $\mathrm{P} \leq 0.05$ (2-tailed); ** Significant at the $\mathrm{P} \leq 0.01$ (2-tailed) 

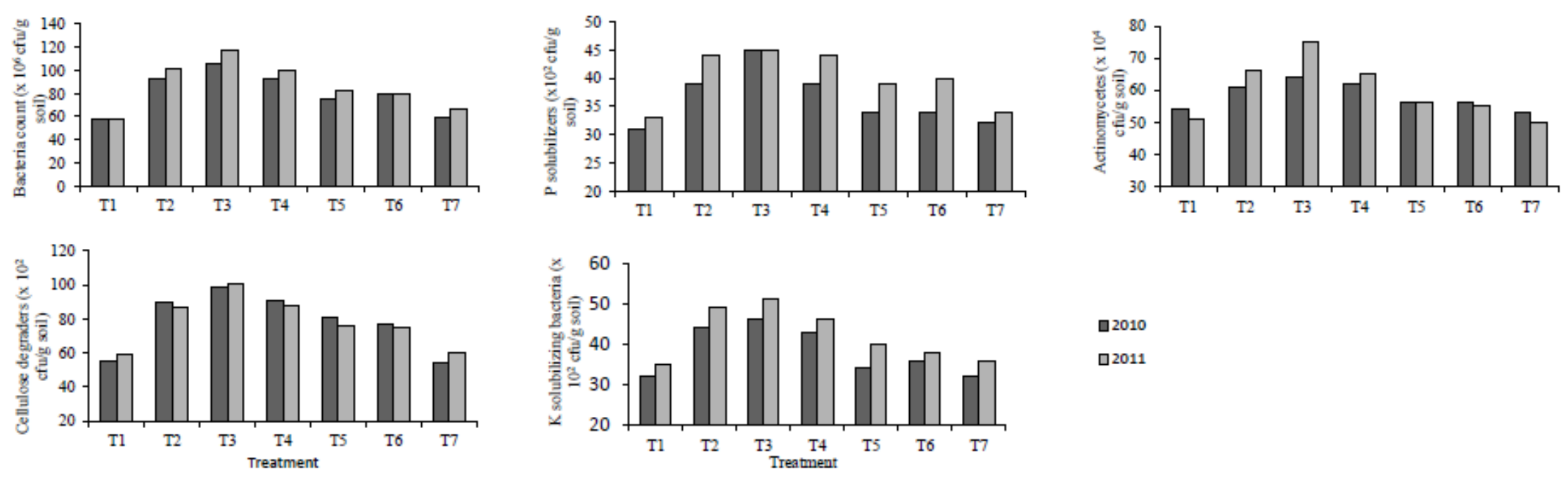

Fig.l Effect of integrated potassium fertilization on microbial counts in rhizospheric soil
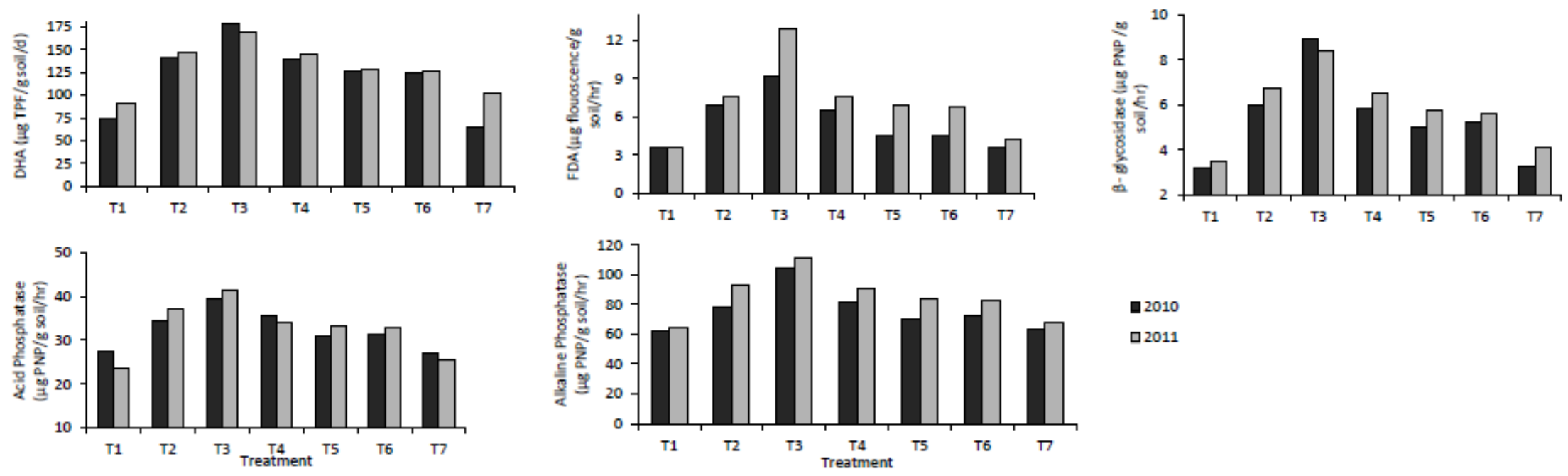

प2010

प2011

Fig.2 Effect of integrated potassium fertilization on enzymatic activity in rhizospheric soil 


\section{Crop productivity}

Results indicate that all the treatments applied with $\mathrm{K}$ showed significant improvement in the yield of corn and wheat crops (Table 2). The highest yield observed in treatment applied with $90 \mathrm{~kg} \mathrm{~K} \mathrm{ha}^{-1}$ supplemented $60 \mathrm{~kg}$ $\mathrm{K} \mathrm{ha}^{-1}$ through MOP and $30 \mathrm{~kg} \mathrm{~K} \mathrm{ha}^{-1}$ through FYM $\left(\mathrm{T}_{3}\right)$ in corn and treatment applied with $90 \mathrm{~kg} \mathrm{~K} \mathrm{ha}{ }^{-1}$ supplemented $60 \mathrm{~kg} \mathrm{~K} \mathrm{ha}{ }^{-1}$ through MOP and $30 \mathrm{~kg} \mathrm{~K} \mathrm{ha}^{-1}$ through FYM $\left(\mathrm{T}_{7}\right)$ in wheat crop. The application of $90 \mathrm{~kg}$ $\mathrm{K} \mathrm{ha}{ }^{-1}$ improved the availability of $\mathrm{K}$ in the soil. The available $\mathrm{K}$ is vital to many plant processes including photosynthesis, translocation of photosynthates, protein synthesis, activation of plant enzymes (IPNI, 1998). Again, integrated $\mathrm{K}$ management involving FYM supplied $\mathrm{N}, \mathrm{P}$ and $\mathrm{K}$ in available forms to the plants through biological decomposition along with micronutrients leading to higher yields. Kumar et al., (2014) reported that integrated use of K (FYM +MOP) recorded significantly higher yield compared to 100\% NP and 100\% NPK fertilizers due to greater availability of macro and micronutrients. Rehman et al., (2008) reported that different levels of NPK and FYM alone or in combination had a significant effect on yield of the wheat crop. Mehdi et al., (2001) reported that increasing $\mathrm{K}$ application resulted in a significant increase in growth and yield of wheat.

\section{Nutrient availability}

Availability of $\mathrm{N}, \mathrm{P}$, and $\mathrm{K}$ declined after harvest of corn (Table 3). The continuous mining of nutrient by the crop resulted in the decline in the nutrient availability irrespective of applied nutrient (Ramamurthy et al., 2009, NAAS report 2006). In the present study, the availability of different nutrients increased due to the slow-release supply of organicallybound nutrients such as N, P through integrated $\mathrm{K}$ management practice
(Mariangela and Francesco 2010; Choudhary and Kumar 2013). Addition of FYM through integrated $\mathrm{K}$ management accelerates the process of mineral weathering and aids insolubilization of plant nutrients from otherwise insoluble minerals. Further, FYM provides slowly available $\mathrm{C}$ and energy source to support a large diverse, metabolically active microbial community, which helps in solubilization and availability of nutrients to crop plants (Wolf and Wagner 2005).

\section{Microbial counts}

Microorganisms have high surface: volume ratio, due to which, they have intimate relations with their surroundings. A change in microbial activity is considered as an indicator for soil improvement and transient changes to various perturbations (Pankhurst $e t$ al., 1995). In the present study, increase in the population of bacteria, actinomycetes, $\mathrm{P}$ solubilizers, cellulose degraders and $\mathrm{K}$ solubilizing bacteria observed under the treatments applied with integrated $\mathrm{K}$ compared to treatments applied with $\mathrm{K}$ through MOP alone or No K treatment (Fig. 1). Compared to chemical fertilizers, integrated $\mathrm{K}$ had a significantly greater impact on the microbial biomass and activity. Firstly, the integrated $\mathrm{K}$ application provided abounding organic matter for the growth and development of living microorganisms in the soils. Secondly, integrated $\mathrm{K}$ application helped in the better growth of plant roots, which also added soil organic matter in the soil for microorganisms (Gong et al., 2009).

\section{Enzymatic activity}

Different enzymes in soil play vital roles. Dehydrogenase activity is considered a good indicator of microbial activity as it reflects the total range of oxidative activity of soil microflora (Nannipieri et al., 1990). 
Phosphatases are important as they help in the release of $\mathrm{P}$ from organic $\mathrm{P}$ (Taylor and Sinsabaugh, 2015). $\quad \beta$-Glucosidase is an enzyme involved in biomass degradation and regarded as an early indicator of changes in soil properties (Ekenler and Tabatabai, 2003). Fluorescein diacetate [3', 6'-diacetyl fluorescein (FDA)] assay has been widely used to assess overall hydrolytic activities of soil microbial communities including bacteria and fungi (Alkorta et al., 2003; Liu et al., 2007). Integrated application of $\mathrm{K}$ increased the activity of different enzymes compared to treatments applied with K through MOP alone or in the treatments applied with No K (Fig. 2 ). The increase in enzymatic activity under integrated $\mathrm{K}$ application was due to more availability of easily decomposable components (organic C) in the form of FYM for the metabolism, growth, and development of soil microorganisms (Gopinath et al., 2007; Gong et al., 2009; Burns et al., 2013). Higher enzymatic activity in treatments applied with $\mathrm{K}$ through MOP alone recorded due to the greater input of root biomass due to better crop productivity which was the result of higher availability in soil for better growth and development of corn plants (Usha et al., 2013; Singh et al., 2015; Heidari et al., 2016).

\section{Correlation studies}

The positive correlation showed that enzymes activities and microbial count played a significant role in yield improvement (Table 4). The activity of microbes and enzymes helps in biomass transformations of the release of nutrients. The increase in microbial activity indirectly showed an increase in microbial biomass which acted as a small but labile reservoir for these elements.

It concluded that integrated $\mathrm{K}$ management significantly increases grain and stover/straw yield of corn-wheat cropping system. Integrated $\mathrm{K}$ management significantly improves the soil biological properties. A direct correlation observed between yield and soil biological properties. Integration $\mathrm{K}$ management could be an alternative option for sustainable management of agricultural land and restore its fertility compared to the application of $\mathrm{K}$ fertilizers alone.

\section{Acknowledgment}

Authors are thankful to Indian Council of Agriculture Research, New Delhi and ICARIndian Agricultural Research Institute, New Delhi to provide financial support and other required facilities.

\section{References}

Alkorta, I., Aizpurua, A., Riga, P., Albizu, I., Amézaga, I. and Garbisu, C., 2003. Soil enzyme activities as biological indicators of soil health. Rev. Environ. health, 18(1), 65-73.

Balota, E. L., Colozzi-Filho, A., Andrade, D. S., and Dick, R. P., 2003. Microbial biomass in soils under different tillage and crop rotation systems. Bio. Ferti. Soils. 38(1), 15-20.

Burns, R.G., DeForest, J.L., Marxsen, J., Sinsabaugh, R.L., Stromberger, M.E., Wallenstein, M.D., Weintraub, M.N., and Zoppinih, A., 2013. Soil enzymes in a changing environment: Current knowledge and future directions. Soil Bio. Biochem. 58, 216-234.

Canarutto, S., Mazzoncini, M., Perna, A., and Cervelli, S., 1995. The effect of reduction of inputs on phosphataseactivity, organic-carbon content and water stability index in a corn cultivated soil. Fres. Environ. Bull. 4(5), 291-296.

Choudhary, V.K. and Kumar, S. P., 2013. Maize production, economics, and soil productivity under different organic source of nutrients in eastern Himalayan region, India. Intern. J. Plant Prod. 7(2), 167-186. 
Clarholm, M., and Rosengren-Brinck, U., 1995. Phosphorus and nitrogen fertilization of Norway spruce forest-effects on needle concentrations and acid phosphatase activity in the humus layer. Plant Soil 175(2), 239-249.

Dibb, D. and Thompson, W., 1985. Interaction of potassium with other nutrients. Potassium in agriculture, pp. 515-533.

Dobermann,A.R.,2001. Crop potassium nutritionimplications for fertilizer recommendations. Agronomy Faculty Publications, pp.357.

Eivazi, F. and Tabatabai, M.A., 1988. Glucosidases and galactosidases in soils. Soil Bio. Biochem. 20,601-606.

Ekenler, M. and Tabatabai, M.A., 2003. Effects of liming and tillage systems on microbial biomass and glycosidases in soils. Bio Fert. Soils. 39, 51-61.

Gomez, K. A., and Gomez, A. A., 1984. Statistical procedures for agricultural research. John Wiley \& Sons.

Gong, W., Yan, X., Wang, J., Hu, T., Gong, Y., 2009. Long-term manure and fertilizer effects on soil organic matter fractions and microbes under a wheat-maize cropping system in northern China. Geoderma 149, 318-324.

Gopinath, K.A., Saha, S., Mina, B.L., Pande, H., Kundu, S., Gupta, H.S., 2007. Influence of organic amendments on growth, yield and quality of wheat and on soil properties during transition to organic production. Nutr. Cycl. Agroecosys.82, 51-60.

Green, V.S., Stott, D.E., and Diack, M., 2006. Assay for fluorescein diacetate hydrolytic activity: optimization for soil samples. Soil Bio.Biochem.38 (4), 693-701.

Heidari, G., Mohammadi, K. and Sohrabi, Y., 2016. Responses of Soil Microbial Biomass and Enzyme Activities to Tillage and Fertilization Systems in Soybean (Glycine $\max$ L.) Production. Fron. Plant Sci. 7, 1730. doi: 10.3389/ fpls.2016.01730

Jackson, M. L., 1967. Soil Chemical Analysis Prentice Hall of India New Delhi.

Klein, D.A., Loh, T.C., and Goulding, R.L., 1971. A rapid procedure to evaluate the dehydrogenase activity of soils low in organic matter. Soil Bio.Biochem. 3(4), 385-387.
Liu, B., Tu, C., Hu, S., Gumpertz, M. and Ristaino, J.B., 2007. Effect of organic, sustainable, and conventional management strategies in grower fields on soil physical, chemical, and biological factors and the incidence of Southern blight. Appl. Soil Eco. 37(3), 202-214.

Mariangela D. and Francesco M. 2010. Long-term effects of organic amendments on soil fertility- A review. Agron.Sustain. Develop. 30 (2), 401-422.

Medzon, E. L., and Brady, M. L., 1969. Direct measurement of acetylesterase in living protist cells. J Bact. 97,402-415.

Mehdi, S.M., Ranjha, A.M., Sarfraj, M. and Hassan, G., 2001. Response of wheat to potassium application in six soil series of Pakistan. J. Bio. Sci. 6, 429-431.

NAAS, 2006. Low and Declining Crop Response to Fertilizers. Policy Paper No. 35, National Academy of Agricultural Sciences, New Delhi. pp 8.

Nannipieri, P., Ascher, J., Ceccherini, M.T., Landi, L., Pietramellara, G. and Renella, G., 2003. Microbial diversity and soil functions. Eur. J. Soil Sci. 54, 655-670.

Nannipieri, P., Grego, S., Ceccanti, B., 1990. Ecological significance of biological activity. In: Bollag, J.-M., Stotzky, G. (Eds.), Soil Biochemistry 6, 293-355.

Nejad, S.D., Nejad, T.S. and Lack, S., 2010. Study effect drought stress and different levels potassium fertilizer on $\mathrm{K}$ accumulation in corn. Nat. Sci. 8,23-27.

Nelson, L. B., and Heidel, H., 1952. Soil analysis methods as used in the Iowa State College Soil Testing Laboratory.

Okore, C.C., Mbanefo, O.N., Adeyemo, S., Onyekwere, B. and Onyewenjo, S., 2012. The effect of mixed organic amendments on the shoot length of Zea mays grown in condemned engine oil polluted soil. Proc. (online), IPCBEE 47:58-62. IACSIT Press, Singapore. DOI: 10.7763/IPCBEE V47.12

Olsen, S. R., 1954. Estimation of available phosphorus in soils by extraction with sodium bicarbonate. United States Department of Agriculture; Washington.

Pankhurst, C.E., Hawke, B.G., McDonald, H.J., Kirkby, C.A., Buckerfield, J.C., Michelsen, P., O’Brien, K.A., Gupta, V.V.S.R. and 
Doube, B.M.,1995. Evaluation of soil biological properties as potential bioindicators of soil health. Aust. J. Exp. Agri. 35, 1015-1028.

Polara, K.B., Sardhara, R.V., Parmar, K.B., Babariya, N.B. and Patel, K.G.,2009. Effect of potassium on inflow rate of $\mathrm{N}, \mathrm{P}, \mathrm{K}, \mathrm{Ca}$, $\mathrm{S}, \mathrm{Fe}, \mathrm{Zn}$ and $\mathrm{Mn}$ at various growth stages of wheat. Asian J. Soil Sci. 4,228-235.

Ramamurthy, V., Naidu, L.G.K., Ramesh, Kumar, S.C., Srinivas, S. and Hegde, R., 2009. Soil based fertilizer recommendations for precision farming. Current Sci. 97(5), 641647.

Rehman, S., Khalil, S. K., Rehman, A. and Saljoqi, A.U.R., 2008. Organic and inorganic fertilizers increase wheat yield components and biomass under rainfed condition. Sarhad J. Agric. 24 (1) 11-20.

Saifullah, Ranjha, A.M., Yaseenand, M. and Akhtar M.E., 2002. Response of wheat to potassium fertilization under field conditions. Pak. J. Agric. Sci. 39 (4), 269272.

Singh, G., Kumar, D. and Sharma, P., 2015. Effect of organics, biofertilizers and crop residue application on soil microbial activity in rice-wheat and rice-wheat mungbean cropping systems in the IndoGangetic plains. Cogent Geosci. 1, 1-14. http://dx.doi.org/ 10.1080/23312041.2015. 1085296

Stanford, G., and English, L., 1949. Use of the flame photometer in rapid soil tests for $\mathrm{K}$ and Ca. Agron. J. 41(9), 446-447.

Steingrobe, B. and Claassen, N., 2000. Potassium dynamics in the rhizosphere and $\mathrm{K}$ efficiency of crops. J. Plant Nutri. Soil Sci.
163,101-106.

Subbiah, B.V., 1956. A rapid procedure for the determination of available nitrogen in soils. Current Sci., 25, 259-260.

Tabatabai, M.A. and Bremner, J.M., 1969. Use of p-nitrophenyl phosphate for assay of soil phosphatase activity. Soil Bio. Biochem. 1: 301-307.

Taylor, D.L. and Sinsabaugh, R.L., 2015. The Soil Fungi: Occurrence, Phylogeny, and Ecology. Soil Microbiology, Ecology and Biochemistry, Fourth Edition. Academic Press. pp 77-109.

Usha Rani I., Padmaja, G. and Chandrasekhar, R.P., 2013. Integrated effect of organic manures and inorganic fertilizers on soil phosphatase activity and yield of maizespinach cropping system. Agric. Sci. Digest. 34(1),31-35.

Walkley, A., and Black, I.A., 1934. An examination of the degtjareff method for determining soil organic matter, and a proposed modification of the chromic acid titration method. Soil sci. 37, 29-38.

Wolf, D.C. and Wagner, G.H., 2005. Carbon transformations and soil organic matter formation. Principles and Applications of Soil Microbiology. Pearson Education Inc., Upper Saddle River, New Jersey (II edi.). pp 320.

Yadav, R. L., Prasad, K., and Gangwar, K. S., 1998. Prospects of Indian Agriculture with special reference to nutrient management under irrigated systems. Long-term Fertility Management through Integrated Plant Nutrient supply. Indian Institute Soil Science Bhopal, India. pp 1-335.

\section{How to cite this article:}

Sanjeev Kumar, Shiva Dhar, Sharmistha Barthakur, M. Chandrakala, S.A. Kochewad, L.R. Meena, L.K. Meena, Sudhir Kumar, Magan Singh and Dileep Kumar. 2018. Effect of Integrated Potassium Management on Soil Biological Properties and Yields of Corn under Corn-Wheat Cropping System. Int.J.Curr.Microbiol.App.Sci. 7(12): 1855-1866. doi: https://doi.org/10.20546/ijcmas.2018.712.217 